\title{
Traumatic acute appendicitis: A case report
}

\section{Travmatik akut apandisit: Olgu sunumu}

\author{
Banu KARAPOLAT ${ }^{1} \odot$, Hatice KÜçÜK² ${ }^{2}$
}

\section{ABSTRACT}

Acute appendicitis and trauma are commonly seen surgical emergencies. Whether or not the trauma is a cause of appendicitis has been subject to discussions for many years.

\begin{abstract}
A 36-year-old male patient presented to our clinic complaining about pain in his right lower abdomen, vomiting and lack of bowel movement. His anamnesis revealed that he fell off a bicycle and his right lower abdominal quadrant hit handlebar of the bicycle approximately 13-14 hours ago. In physical examination, tenderness to palpation, guarding and rebound tenderness in right lower abdominal quadrant were detected. Laboratory tests showed that hemoglobin was $12.6 \mathrm{~g} / \mathrm{dL}$ and leukocyte 21.600/ $\mathrm{mm}^{3}$. In abdominal ultrasound, the diameter of appendix was measured to be $10 \mathrm{~mm}$ and an increased density and edema were found in appendiceal mesentery and periappendiceal adipose tissue. Abdominal tomography showed that the diameter of appendix was $11 \mathrm{~mm}$. The patient was urgently operated. During exploration, intense hematoma was seen in the root, wall and mesentery of the edematous appendix. Mesoappendix with hematoma was also resected during appendectomy. After pathological examination of the removed specimen, the case was reported to be an acute gangrenous appendicitis. The patient was asymptomatic after 6 months of follow-up.
\end{abstract}

Although rarely, acute appendicitis may be develop after a serious blunt abdominal trauma. Clinicians should absolutely suspect acute appendicitis especially in cases with right lower quadrant pain and tenderness following a blunt abdominal trauma for early management and an uneventful postoperative course.

Keywords: Trauma, blunt, acute abdomen, acute appendicitis, appendectomy

\begin{abstract}
öz
Akut apandisit ve travma sıklıkla görülen cerrahi acillerdendir. Travmanın apandisite neden olup olmadığı uzun yıllardır tartışma konusu olmuştur.
\end{abstract}

Otuz altı yaşında erkek olgu sağ alt karın bölgesinde ağrı, kusma ve bağırsaklarının çalışmaması yakınmaları ile başvurdu. Olgunun anamnezinde yaklaşık olarak 13-14 saat önce bisikletten düşerek batın sağ alt kadranını bisikletin gidonuna çarptığı öğrenildi. Fizik muayenede batın sağ alt kadranda palpasyonla hassasiyet, defans ve rebaund mevcuttu. Laboratuvar tetkiklerinde hemoglobin $12,6 \mathrm{~g} / \mathrm{dL}$ ve lökosit $21,600 / \mathrm{mm}^{3}$ olarak belirlendi. Batın ultrasonografisinde apendiks çapı $10 \mathrm{~mm}$ olarak ölçüldü, apendiks mezenteri ve periapendisiyel yağ dokusu içerisinde yoğunluk artışı ve ödem belirlendi. Abdominal tomografide ise apendiks çapı $11 \mathrm{~mm}$ idi. Olgu acil olarak operasyona alındı. Eksplorasyonda ödemli apendiksin kök, duvar ve mezosunda yoğun hematom görüldü. Olguda apendektomi işlemine hematomlu apendiks mezosunun rezeksiyonu da eklendi. Çıkarılan spesmenin patolojik incelemesi akut gangrenöz apandisit olarak raporlandı. Olgu 6 aylık takibin sonunda asemptomatiktir.

Nadir de olsa ciddi künt batın travmaları sonrasında akut apandisit gelişebilmektedir. Klinisyenler künt batın travmasını takiben özellikle sağ alt kadran ağrısı ve defans bulunan olgularda erken tanı ve sorunsuz bir postoperatif dönem için akut apandisitten kesinlikle şüphelenmelidirler.

Anahtar kelimeler: Travma, künt, akut batın, akut apandisit, apendektomi

\section{INTRODUCTION}

Acute appendicitis is the most frequently seen cause of acute abdomen in younger adults ${ }^{1}$. The pathologi- cal process of an acute appendicitis usually onsets due to presence of obstruction of the appendiceal lumen with fecalith, bacterial, and viral infections, lymphoid tissue hyperplasia, intestinal parasites,

Received: 24.04 .2018

Accepted: 01.08 .2018

${ }^{1}$ Department of General Surgery, Kanuni Training and Research Hospital, Trabzon, Turkey

${ }^{2}$ Department of Pathology, Kanuni Training and Research Hospital, Trabzon, Turkey

Corresponding author: Banu Karapolat, Department of General Surgery, Kanuni Training and Research Hospital, Trabzon, Turkey e-mail: banukarapolat@hotmail.com

ORCID ID's:

B.K. 0000-0001-5132-8266, H.K. 0000-0002-3724-9104 
barium, food, foreign objects, fibrous bands, or carcinoid tumors ${ }^{1-3}$. This process may progress to peritonitis and intraabdominal abscess via appendiceal inflammation and perforation.

Because of the small size and high mobility of the appendix, blunt abdominal traumas can very rarely be one of the causes of acute appendicitis ${ }^{4,5}$. Actually, the mechanism of acute appendicitis that occurs due to a blunt trauma has not been fully clarified. The possible pathophysiological mechanism here is that, blunt abdominal trauma may cause appendiceal edema, inflammation and hyperplasia of appendiceal lymphoid tissue with subsequent obstruction of the appendiceal lumen ${ }^{6}$.

In this paper, we intended to present a case of acute appendicitis that was associated with a blunt abdominal trauma due to falling off a bicycle.

\section{CASE PRESENTATION}

A 36-year-old male patient presented with complaints of pain in his right lower abdominal region, vomiting and lack of bowel movement. Any other remarkable features or drug use could be detected in the patient's history. He was healthy before the accident, his anamnesis revealed that he fell off a bicycle and hit his right lower abdominal quadrant on the handlebar of the bicycle approximately 13-14 hours ago. Among his vital signs, the arterial blood pressure was $120 / 65 \mathrm{mmHg}$, pulse rate $84 / \mathrm{min}$, respiration rate $21 / \mathrm{min}$, and body temperature $37.5^{\circ} \mathrm{C}$. In physical examination, no signs of trauma were visible, but there were tenderness to palpation, guarding and rebound tenderness in right lower abdominal quadrant. Laboratory tests showed that hemoglobin was $12.6 \mathrm{~g} / \mathrm{dL}$ (range, $14-20 \mathrm{~g} / \mathrm{dL}$ ), leukocyte 21.600/

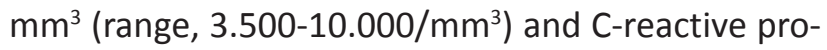
tein $8.3 \mathrm{mg} / \mathrm{dL}$ (range, $0-0.5 \mathrm{mg} / \mathrm{dL}$ ). In abdominal ultrasound, the diameter of appendix was measured to be $10 \mathrm{~mm}$ and an increased density and edema were found in appendiceal mesentery and periappendiceal adipose tissue. In abdominal tomography, solid organ injury and intraperitoneal fluid were not

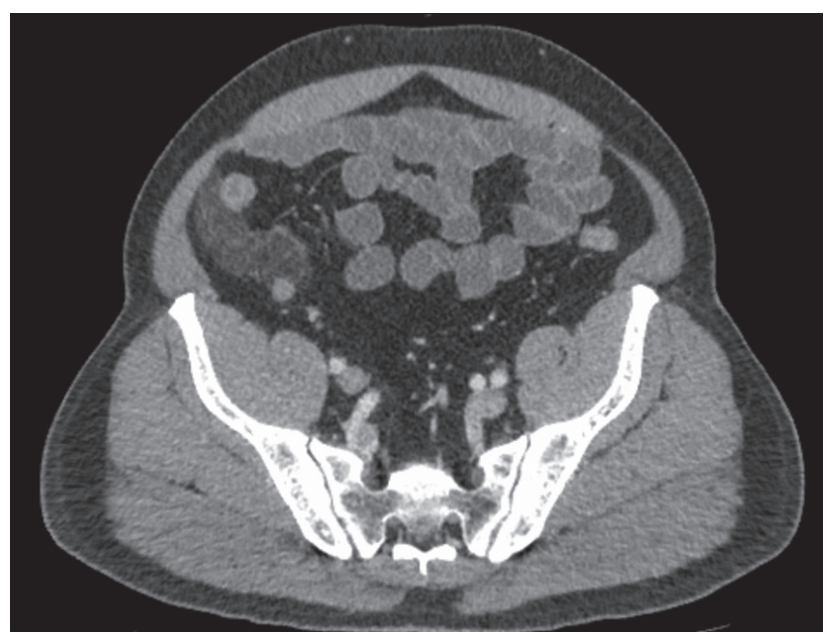

Figure 1. Abdominal tomography image of the patient's.

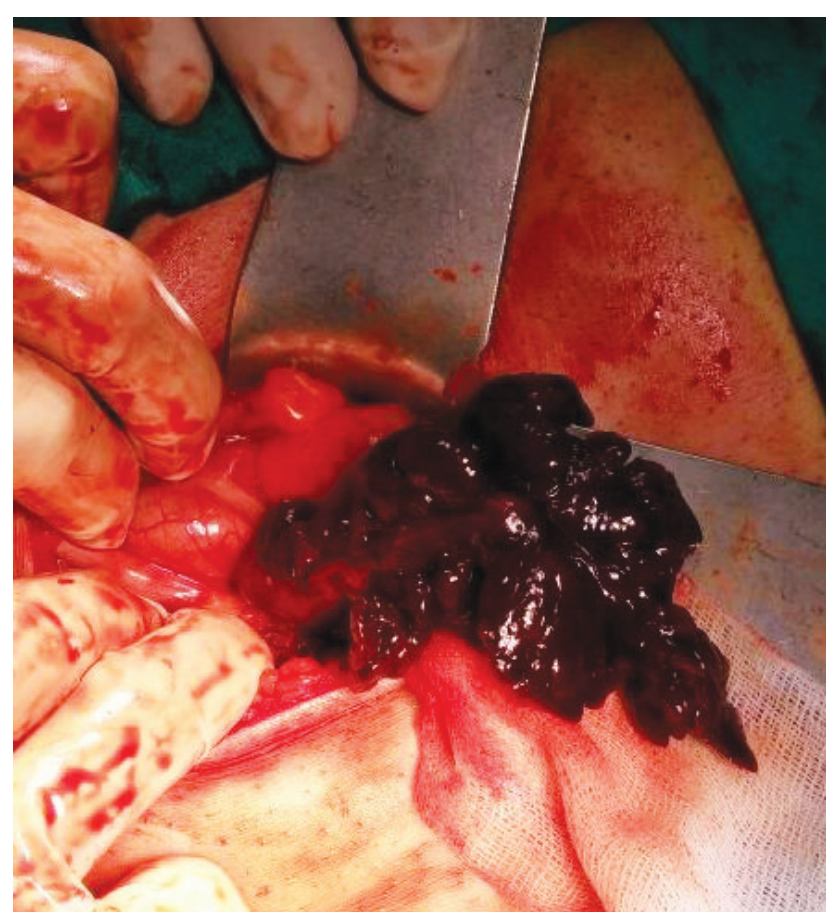

Figure 2. This peroperative image shows that the appendix is edematous and there is intense hematoma in its root, wall and the mesoappendix.

detected, but the diameter of appendix was $11 \mathrm{~mm}$ and there was increased density in periappendiceal mesentery, which was interpreted as acute appendicitis (Figure 1). Ninety minutes after admission to the hospital, the patient was urgently taken to the operation. A McBurney's incision was performed, and intraabdominal organs were examined in terms of trauma. Appendix was edematous and non-per- 


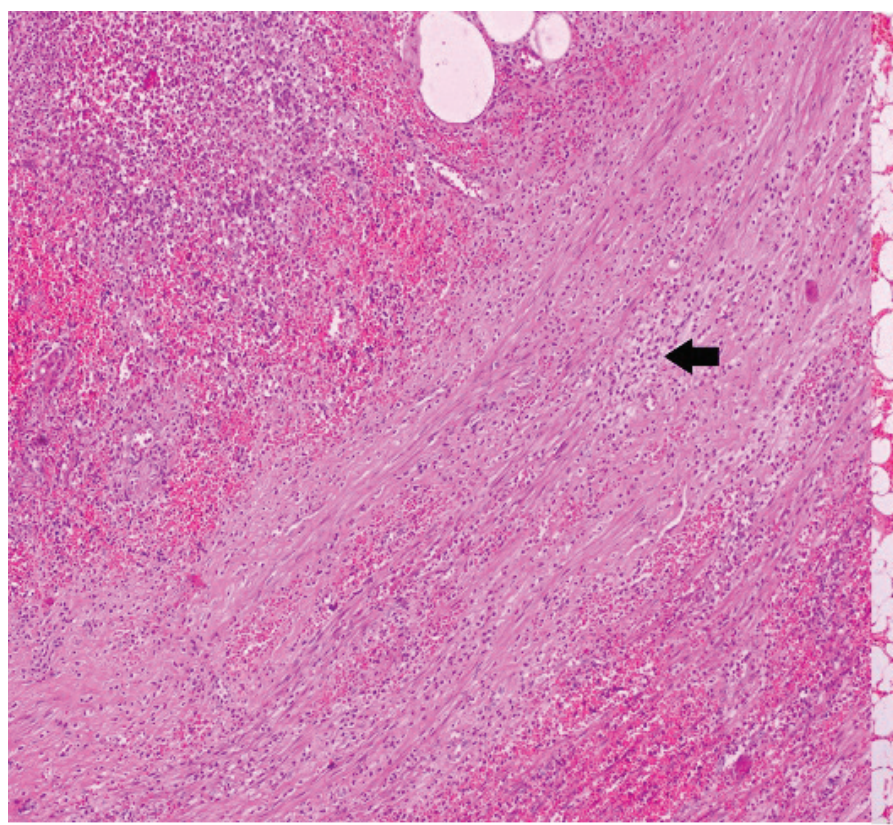

a

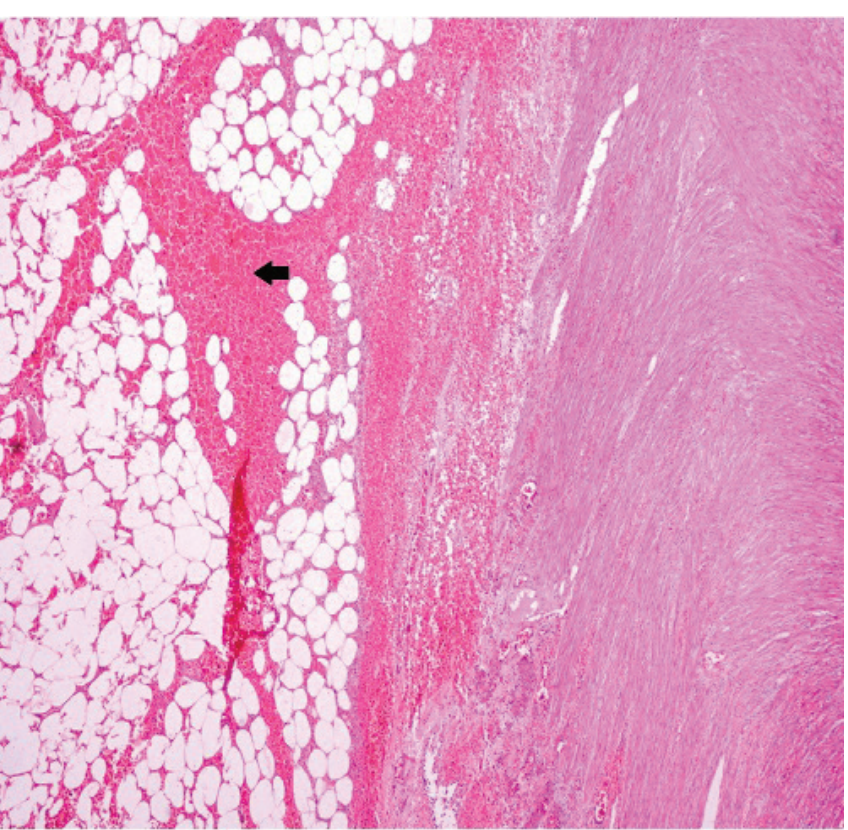

b

Figure 3. a) Polymorphonuclear leukocyte infiltration in the appendix wall (black arrow), b) Areas of hemorrhage within periappendiceal adipose tissue (black arrow).

forated. During the exploration, intense hematoma was seen in the root, wall and mesentery of the appendix (Figure 2). Resection of the mesoappendix with hematoma was performed during appendectomy. No complications developed in the patient in the postoperative period and he was discharged at day 3. After the pathological examination of the removed specimen, the case was reported to be an acute gangrenous appendicitis and congested periappendiceal adipose tissue with hematoma (Figure $3)$. The patient was asymptomatic after 6 months of postoperative follow-up.

\section{DISCUSSION}

Acute appendicitis is one of the most frequently encountered pathologies in general surgery clinics requiring an operation ${ }^{7}$. Any delay in the diagnosis of acute appendicitis may result in complications such as appendiceal perforation, peritonitis, periappendiceal abscess, plastron appendicitis and sepsis, increasing the morbidity-mortality rates. In acute appendicitis, the correct diagnosis can actually be made most of the time with both anamnesis and clinical, physical examination ${ }^{7}$. But, anamnesis and physical examination can be misleading in cases with posttraumatic acute appendicitis, often leading to difficulties in diagnosis. Any diagnostic delay did not occur in our case due to typical anamnesis, and positive physical examination and laboratory findings. Only the fact that the patient had an abdominal trauma before the clinic of appendicitis emerged made us think that pathologies such as liver injury, intestinal perforation and retroperitoneal hematoma might have occurred, therefore, abdominal ultrasound and a more advanced radiological examination, complete abdominal tomography were performed.

There are several theories about the pathogenetic mechanism of appendicitis following a blunt abdominal trauma. First one is related to the sudden increase in the intraabdominal pressure after the trauma and the resulting increase in the intraceacal pressure leading to rapid distention and impaired blood flow in the appendix. Secondly, the appendiceal lumen, which is partly obstructed with fecalith, becomes fully obstructed secondary to posttraumatic mucosal activation. Thirdly, the appendix is being squeezed by the iliac bone during the trauma and the resulting laceration and mucosal damage in- 
duced the development of appendicitis. Fourth, the trauma is directly causing damage to the appendix ${ }^{8,9}$. In our case, a seriously large hematoma occurred in the appendiceal wall and mesoappendix, and in the periappendiceal adipose tissue. We think that this hematoma led to ischemic necrosis by impairing the blood flow of the appendix and with the pressure the hematoma exerted on the appendiceal lumen, narrowing occurred in the lumen. Due to both of these mechanisms, appendiceal edema, acute inflammation and hyperplasia of appendix lymphoid tissue occurred resulting in obstruction of the appendiceal lumen and acute appendicitis.

In the present case, the lack of any appendicitis-related findings or symptoms before the trauma, the onset of appendicitis within 6-48 hours after the direct abdominal trauma, the presence of a seriously large hematoma in the appendiceal wall and mesoappendix and in the periappendiceal adipose tissue during the exploration, without any relevant histopathological finding obstructing the lumen made us think that the blunt abdominal trauma may have been effective in the etiology.

\section{CONCLUSION}

Acute appendicitis presenting diagnostic difficulties may develop in rare cases due to some multifactorial complex mechanisms after a severe blunt abdominal trauma. Clinicians should absolutely suspect acute appendicitis especially in cases with right lower quadrant pain and tenderness following a blunt abdominal trauma. Abdominal ultrasound and abdominal tomography are useful diagnostic tools. The classical surgical appendectomy incision and appendectomy which will be performed in the early period will provide an uneventful management and postoperative course.

\section{Acknowledgments}

Written consent was obtained from the patient to use medical records and images in the publication of this manuscript.

\section{REFERENCES}

1. Bhangu A, Søreide K, Di Saverio S, Assarsson JH, Drake FT. Acute appendicitis: modern understanding of pathogenesis, diagnosis, and management. Lancet. 2015; 26;386(10000):127887.

2. Etensel B, Yazici M, Gürsoy H, Ozkisacik S, Erkus M. The effect of blunt abdominal trauma on appendix vermiformis. Emerg Med J. 2005;22(12):874-7. https://doi.org/10.1136/emj.2004.018895

3. Tekin K, Ozek MC. Acute appendicitis after blunt abdominal trauma. Ulus Travma Derg. 2001;7(3):207-9.

4. Ramesh G, Ho PW, Ng KL, Jegan T. Appendicitis following blunt abdominal trauma. Med J Malaysia. 2002;57(1):123-4.

5. Ciftci AO, Tanyel FC, Büyükpamukçu N, Hiçsönmez A. Appendicitis after blunt abdominal trauma: cause or coincidence? Eur J Pediatr Surg. 1996;6(6):350-3.

https://doi.org/10.1055/s-2008-1071013

6. Bouassria A, Ibn Majdoub K, Yazough I, Ousadden A, Mazaz K, Taleb KA. Traumatic appendicitis: a case report and literature review. World J Emerg Surg. 2013;8(1):31. https://doi.org/10.1186/1749-7922-8-31

7. Oguzturk H, Turtay G, Ertan C, Tekin YK, Eren SH. Complexities of the acute appendicitis diagnosis: two case reports. Cumhuriyet Med J. 2009;31:441-4.

8. Altunkas A, Ozcaglayan TI, Celik AO, Sumbul A. Postraumatic appendicitis; is it true or rumor? Abant Med J. 2015;4(1):67-9.

https://doi.org/10.5505/abantmedj.2015.05025

9. Toumi Z, Chan A, Hadfield MB, Hulton NR. Systematic review of blunt abdominal trauma as a cause of acute appendicitis. Ann R Coll Surg Engl. 2010;92(6):477-82. https://doi.org/10.1308/003588410X12664192075936 